\title{
Special Features of Foreign-Languages Teaching at Higher Education Institution
}

Oksana V. Petrenko ${ }^{1}$, Iana E. Andriushchenko ${ }^{2}$, Hanna M. Truba ${ }^{3}$, Vladyslava V. Shcherbytska ${ }^{4}$ \& Lesia I. Syniavska ${ }^{5}$ ${ }^{1}$ Department of Language and Humanitarian Disciplines No. 3, Medical Faculty No. 3, Donetsk National Medical University, Mariupol, Ukraine

${ }^{2}$ Department of Hotel and Restaurant Business and Business Organization, Management Faculty, Mykolaiv National Agrarian University, Mykolaiv, Ukraine

${ }^{3}$ Department of Applied Linguistics, Faculty of Ukrainian Philology, Odessa I. I. Mechnikov National University, Odessa, Ukraine

${ }^{4}$ Department of International Translation, Foreign Philology and Special Language Training, Faculty of Economics, Business and International Relations, University of Customs and Finance, Dnipro, Ukraine

${ }^{5}$ Department of Foreign Literature, Faculty of Romance and Germanic Philology, Odessa I. I. Mechnikov National University, Odessa, Ukraine

Correspondence: Oksana V. Petrenko, Donetsk National Medical University, Medical Faculty № 3, 80 Shevchenka str., Mariupol, 87539, Ukraine.

Received: June 10, 2020

Accepted: August 3, 2020

Online Published: August 10, 2020

doi:10.5430/ijhe.v9n7p298

URL: https://doi.org/10.5430/ijhe.v9n7p298

\begin{abstract}
The trend towards the development of intercultural communicative competences of students, the use of interactive teaching methods, the changing role of a teacher to a consultant in the teaching process necessitates highlighting the level of perception, knowledge and views of teachers on the intercultural approach in teaching. Based on the study of the experience of EU countries in the implementation of intercultural approach in the teaching of foreign languages and an enquiry of 32 teachers, the level of teachers' perception of the intercultural approach was assessed. We have established the next points: 1) changes in the social and economic context require new approaches to the organization and provision of foreign language education; 2) shifting away from linguistic purity and correctness and the priority of a democratic society, openness to different cultures. This indicates that the social and educational environments are multilingual. The study proves a positive perception in increasing the level of knowledge concerning teachers' intercultural communicative competences. Teachers confirm the importance of implementing an intercultural approach in teaching foreign languages. The scientific paper proves the convergence of developing countries, to advanced countries in the implementation of an intercultural approach to teaching foreign languagesat the local level. Nevertheless, the perception of intercultural competences as the best approach to teaching is at a mean level in Ukraine compared to EU countries.
\end{abstract}

Keywords: foreign-language teaching, student curricula, multiculturalism, teaching model, hybrid learning

\section{Introduction}

Global changes in the social and economic system have led to the transformation of the requirements of society, the state and business. That is why we have a result in a changingof the role of foreign-language teaching in higher education institutions. There is a change in the priorities of the goals and objectives of teaching with an emphasis on professional English in order to master the hard skills of these professionals. Students' curricula are becoming utilitarian all over the world due to the necessity of the student, the future specialist to solve professional problems.Most higher education institutions focus on international testing systems rather than internal exams. That is why curricula are based on online materials, thematic series and Cambridge manuals. Herewith, teaching foreign languages in developing countries is based on traditional, not effective in modern dynamic conditions, approaches, teaching methods in accordance with the state policy of teaching. As a result, students are insufficiently motivated, which affects the level of knowledge of foreign languages (Oktay, 2015). An additional factor, deepening the problem, centers around the insufficient level of use of interactive methods of teaching a foreign language. This determines the lack of opportunities for students to actively participate in the teaching process, because the teaching 
process is "teacher-oriented" (Oktay, 2015), whereas the teacher should act as a consultant (Pozdeeva \& Obskov, 2015) and form a clear goal of teaching. One of the purposes of learning a foreign language is to use it in professional activities. The lack of understanding by students of this goal leads to insufficient teaching process and low motivation. As a result, students are not independent enough in learning foreign languages (Prokhorets, Sysa \& Rudneva, 2015).

Taking into consideration the latest global trends in teaching foreign languages, such as: the development of intercultural communicative competences of students, the use of interactive teaching methods, the study of intercultural competences of teachers is an important subject matter of the investigation. Forasmuch as the teacher is responsible for the final effectiveness of teaching foreign languages, due to the fact that he determines the goals, approaches, teaching methods, it is advisable to study the features of teaching foreign languagesin detail in developing countries. Taking into consideration that students from 158 countries can study in Ukraine (as of 2020, there are 80470 foreign students from India, Morocco, Azerbaijan, Turkmenistan, Nigeria, Turkey), and the basic languages of instruction are Ukrainian, Russian and English (Ministry of Education and of Science of Ukraine), the need arises to strengthen the intercultural competences of teachers of higher educational institutions.

The purpose of the investigation is to study the features of teaching foreign languages on the basis of quantitative assessment of teachers'intercultural communicative competence of higher educational institutions of Ukraine.

RQ1: What is the knowledge level of teachers' intercultural communicative competences in the process of teaching foreign languages at higher educational institutions?

RQ2: What is the level of desire and perception by teachers of an intercultural approach to teaching foreign languages at higher educational institutions?

\section{Literature Review}

There are a number of trends in the foreign-language teaching in higher education institutions. The main one is the high level of usage of information and communication technologies. As the number of students who are studying foreign languages increases, so the number of teachers and curricula are also getting higher. The growing demand of students for language and communicative competence determines the usage of the most effective tools of the informational and communicational technologies for the development of these competencies: correspondence by e-mail, online platforms and tools, PowerPoint presentation, training programs on CD-ROM, internet resources (Bilyalova, 2017).

Approaches to the presentation of educational materials, testing and control, the relationship between student and teacher, teaching styles have already changed. Because of using the informational and communicational technologies in the teaching processes, the term "hybrid learning" emerged. It means the usage of foreign-language teaching methods, which are based on the integrated interactive components and innovative technologies in the traditional learning process (Klimova \& Kacetl, 2015).

The internationalization of foreign language teaching in higher education institutions has necessitated the development of new curricula. As a result, the foreign component of teaching is integrated into national curricula. Elements of the educational system are being transformed: student - teacher - educational material. Such changes have a positive effect on intercultural competencies and communication (Grigorieva, 2014).

Throughout the world, the development of "intercultural communicative competence" (Shulga, 2017; Yang, Xiang \& Chun, 2018) is becoming an increasingly common direction in the study of foreign languages. The principles of social and culturalunderstanding of language and culture have begun to be introduced in the countries of Europe, North America and Australia since the end of the 20th century (Yang et al., 2018). The importance of multilingual identity of teachers (Calafato, 2019) on the basis of intercultural approach is confirmed by the growing number of multilingual students, and, accordingly, the prevalence of teaching several foreign languages (Calafato, 2019).At the same time, with the growth of the number of multilingual students, due to the increased mobility of students on a global scale, a "convergence of policies" in teaching foreign languages is taking palce, as well as"ostensible homogenization of European higher education systems around an Anglo-American model" (Pérez-Llantada, 2018). Teaching should be based on the principles of "flexibility, mobility, fluidity and self-development" (Gural, 2014). Flexible formats of teaching foreign languages are adapted to the needs of students (Klimova \& Kacetl, 2015; Arrosagaray, González-Peiteado, Pino-Juste \& Rodríguez-López, 2019). As a result, teaching becomes personalized, adapted to the specific needs of the student; it provides the student's active participation in learning.

Modern features of foreign-languageteaching in higher education institutions include (Klimova \& Semradova, 2012): 
1. Focus on the student and his/her abilities, cultural characteristics, due to integration of psychology and humanistic pedagogy into the teaching process. The theory of social constructivismis the driving force behind the development of the trend, which involves the formation of knowledge based on the experience in the process of active teaching.

2. Integration into the processes of teaching the concept of autonomous learning on the basis of the information and communication technologies.

3. Co-education and increasing the value of cooperation, which ensures the development of students' communication competencies and general team work. A project approach is used.

4. The integration of subject curricula, which means the usage of skills by students (Content and Language Integrated Learning (CLIL).

5. Diversity, which means removing the boundaries between students of different nationalities, ethnicities, social classes and other social and demographic characteristics.

6. The integration of neurolinguistics and psycholinguisticsin the teaching process. In particular it is about the study of motivation to learn foreign languages which is actively used in order to study the role of motivational stimuli.

7. Appearing of the concepts of multiculturalism (Tolosa, Biebricher, East \& Howard, 2018) and multilingualism to ensure openness of students and the study of at least two languages. The level of importance of teaching specialists with intercultural communication skills, professional and cultural communication skills is growing (Bukach \& Golubova, 2019).

8. Introduction of lifelong learning and perception of learning a foreign language as a lifelong process.

"A bi-/multiliteracy genre-based pedagogy can support linguistic diversity on campus". In EU countries, students face problems of "complex multilingual interactions". Herewith, the importance of ensuring plurilingualism at the national level has been emphasized in recent studies (Pérez-Llantada, 2018); it significantly affects the policy of teaching foreign languages at the level of higher educational institution. The effectiveness of communication in various foreign languages depends neither on knowledge of communication norms nor knowledge of the grammar of foreign languages. This reinforces the importance of applying an intercultural approach in teaching a foreign language (Pérez-Llantada, 2018).

\section{Data and Methods}

\subsection{The Concept and Methods of Assessment}

The investigation is based on the concepts of bi- / multiliteracy genre-based pedagogy, plurilingualism and intercultural approach in teaching foreign languages, providing the development of "intercultural communicative competence" of teachers of higher educational institutions (Pérez-Llantada, 2018; Shulga, 2017; Yang et al., 2018).

The study is based on statistical analysis of survey data (Romanowski, 2016). At the first stage of the study, an analysis of modern approaches in teaching foreign languages based on bibliometric analysis of publications (February-March 2020) has been conducted. An analysis of the research based on the database Science Direct and ResearchGate for the period 2006-2020 to study the state of foreign language teaching at higher educational institutions has been used. Moreover, comparison and matching of various Eurostat (2019a, 2019b) data concerning the level of foreign-language learning by students in the EU have been applied. Theoretical generalization of major trends and problems in teaching foreign languages has also been imposed. The principle of historicism has been used in order to analyze changes in trends inteaching foreign languages.

At the second stage of the analysis the methods of studying the state of realization of the intercultural approach in teaching foreign languages at higher educational institutions have been chosen.Forasmuch as the survey is a quantitative method of assessing the features of teaching foreign languages, the questionnaire has been chosen as a tool to conduct a survey proposed by Sercu (2006). The questionnaire makes it possible to determine the level of the teacher's cognition (beliefs, knowledge, thinking) regarding knowledge about the "intercultural communicative competence" of teachers of higher educational institutions. The questionnaire contains 10 statements on "teachers' knowledge about intercultural communicative competence", teachers' knowledge and "teachers' objectives in teaching intercultural communicative competence" (Yang et al., 2018). All 10 statements were likert-scale questions on a range from 1-5 (1 indicating strongly disagree; and 5 indicating strongly agree). 
Intercultural approach analysis in EU countries based on Science Direct database for 2006-2020 period. February - March 2020

- The results are conceptual framework identification, methods and research tools choosing. The questionnaire creation.

Sample identification and data processing. May 2020

- The result is respondents database creation. The data was gathered from respondents.

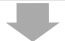

Data analysis based on statistics methods. June 2020

Figure 1 provides information about the stages and methods of research.

Figure 1. Stages and methods of the investigation

Source: author's research

\subsection{Sampling and Data Collection Process}

The study involved 32 foreign language educators (English as the most common) of higher educational institutions in Ukraine with the largest number of foreign students (V. N. Karazin Kharkiv National University, Kharkiv National Medical University and Taras Shevchenko National University of Kyiv, Odessa National Medical University, Vinnytsia National Medical University named after M.I. Pirogov).

The questionnaire was developed by using Google Form and sent to respondents via e-mail.The data collection process was conducted in May, 2020. Table 1 shows the profiles of 32 respondents. 'Email questionnaires are cost-effective and allow respondents to answer questions at their own convenience' (Ghorbani \& Alavi, 2014, p. 5). The announcement of the survey was made by informing the coordinators of higher educational institutions. Questionnaires for the survey were sent to interested foreign language educators.

Table 1. Sample characteristics

\begin{tabular}{llcc}
\hline Variables & Sex & Count & Proportion \\
\hline Gender & Male & 5 & $15.63 \%$ \\
Educational level & Female & 27 & $84.38 \%$ \\
& Bachelor & 4 & $12.50 \%$ \\
Professional title & Master & 7 & $21.88 \%$ \\
& Ph.D. & 21 & $65.63 \%$ \\
Teaching experience & Lecturer & 4 & $12.50 \%$ \\
& Associate professor & 3 & $9.38 \%$ \\
& Other & 25 & $78.13 \%$ \\
& Within 5 years & 21 & $65.63 \%$ \\
& 5-10 years & 5 & $15.63 \%$ \\
& $11-15$ years & 4 & $12.50 \%$ \\
& More than 15 years & 2 & $6.25 \%$
\end{tabular}

Source: author's research

\subsection{Measure Statistics Methods}

The Statistical Package of Social Sciences has been used to process the results of the questionnaire (SPSS version 20.0). The basic statistical methods have been selected as follows:

1. Cronbach's alpha as a coefficient for assessing the reliability of the results (where 0 - low reliability, 1 - very high reliability of the results). 
2. Descriptive statistical coefficients: mean values, minimum, maximum and range, standard deviation.

3. Pearson Correlation analysis has been applied to identify the link between assessments of intercultural communicative competences.

\section{Results and Disscussion}

\subsection{Intercultural Communicative Competence and Intercultural Approach in EU Countries}

Changing of the didactic and methodological strategic goal of foreign-language teaching in response to the challenges of modern reality allows to teach a foreign language not in the context of the educational process of higher education. However, in the context of integrative and optimal means of student personality development. It meets modern requirements for professional training of a competent specialist.

The introduction of a new format of foreign-language teaching has unlimited possibilities in the modern educational process of higher education institutions. The first thing is that the educational discipline "Foreign Language" has a number of potential opportunities for personal and professional development of a student. And this is not only an opportunity to develop communicative and social qualities. The relative freedom of the teacher to choose the content of the material for students and practicing of lexical or grammatical skills allows to enrich the lessons with professional content, promoting professional development.

Secondly, the specific nature of teaching a foreign language requires the development of communication skills and involves working in groups, pairs in the framework of interactive pedagogical learning technologies. Enriching the tasks with professional content for dialogues and texts for listening will also contribute to the development of a professional level of foreign language proficiency and, at the same time, will increase the motivation to learn a foreign language.

Thirdly, the increase in motivation to learn a foreign language not only at the sublevel of survival. Also at the professional level due to the usage of not only competency approach, but also problematic and information, integrative, cultural and other approaches.

The application of the problematic and information approach provides the formation of a specialist in the gradual logical development starting from creative thinking through creative common activities to a creative personality.

The integrative approach is closely linked to the ability to integrate the educational discipline "Foreign Language", when the selection of content meets all professional motives and needs. It is necessary to have an interdisciplinary integration of professionally oriented content of foreign language teaching in order to master language competence at the professional level. It is important to integrate various forms of language and educational activities, providing opportunities for practical development of language skills (video communication, Internet communication, etc.).

It is fundamentally necessary to have a culturological approach in preparation for intercultural interaction. The application of the culturological approach in education involves the disclosure of the axiological, activity orientated, personal and creative aspects of the culture through the understanding of man as a subject of culture. The formation of biculturalism as the ability to perceive the world in different cultural traditions is one of the tasks of language learning (Figure 2). 95\% of students in upper secondary education in the EU study English as a foreign language as of 2017. 100\% of students study two or more foreign languages in Romania, 99.7\% - in France, 99.0\% - in the Czech Republic, Slovenia and Finland. In Italythe number is 24.9\%, in Spain - 29\%, in Poland $-71.9 \%$, in Greece only - 1\%, in Portugal - 6\% (as of 2017). The study of two foreign languages by students is important in terms of further professional benefits: economic and labor ones. Bilingualism provides an economic effect: wages are increased by $20 \%$ of students who have studied two foreign languages (Cappellari \& Di Paolo, 2018). The level of language training also affects the economic integration of migrants, which is especially relevant for internationalized EU countries (Lochmann, Rapoport, \& Speciale, 2019). Accordingly, these economic effects prove the importance of an intercultural approach in foreign language teaching in EU countries. Therefore, the national policy of EU countries is primarily aimed at ensuring bilingualism, multilingualism. Currently, in EU countries "bi- / multiliteracy genre-based pedagogy" is being developed (Pérez-Llantada, 2018) as well as the concept of plurilingualism. Taking into consideration that foreigners' understanding of each other is not determined by knowledge of grammar, communication standards, EU countries agree on the implementation of a policy of an intercultural approach in teaching a foreign language (Pérez-Llantada, 2018). Teaching aims to develop cognitive language skills in a multilingual environment (Lorenzo, Granados, \& Ávila, 2019). 


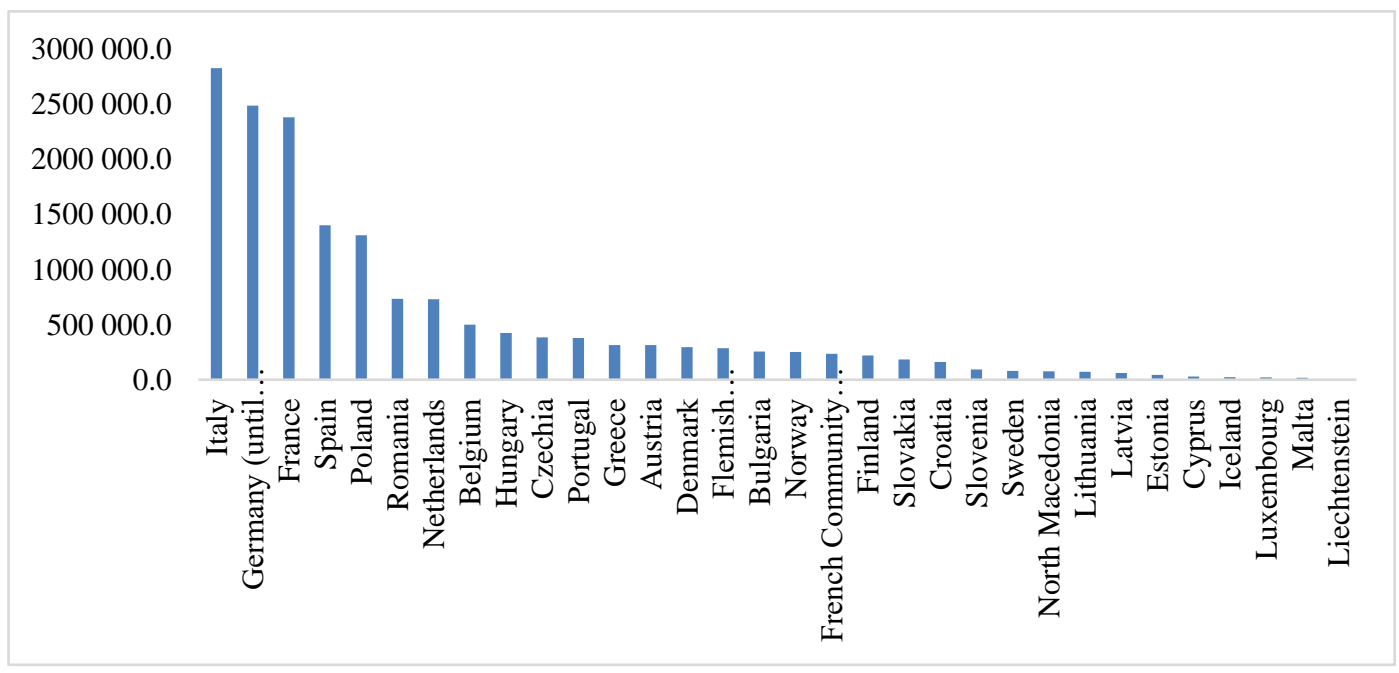

Figure 2. Corresponding (total) number of students enrolled of modern foreign languages studied - absolute numbers of pupils, upper secondary education in EU, 2017

Source: Eurostat (2020)

English, Spanish, French and German are most often studied by students $(94.7 \%, 22.3 \%, 14.1 \%$ and $17.4 \%)$. Intercultural communication is due to the movement of labor, migration within the EU, the expansion of the EU and the some special features of society. So, in some EU countries two or three official languages are legalized, in others - languages of the local minority. For example, $100 \%$ of Swedish, Romanian, Maltese, Dutch students study English in upper secondary education. Spanish is taught by $73.5 \%$ of French upper secondary students, $41.5 \%$ of Swedish students and $20.6 \%$ of German students.

The low level provision with language courses at the expense of employers is the main problem in foreign-language learning (7.9\%).It is also about restrictions on multilingual competencies, low level of fluency (4 out of 10 students), lack of teachers in certain subjects, inconsistency of skills that was acquired as a result of experience in foreign languages and academic teaching, the necessity for teachers to master digital teaching skills (EUR-lex: Access to Eropean Union law, 2019).

In 2008 the European Commission adopted a Communication titled "Multilingualism: an asset for Europe and a shared commitment" (COM (2008) 566 final), which formed the basis of the multilingualism policy development strategy (2008 / C 320/01). The language competences were developed to ensure EU cooperation in multilingualism policy in 2014. A comprehensive approach has been introduced within the EU which deals with foreign language teaching policy. It was introduced in order to achieve specialized foreign language skills, implement the concept of awareness, and promote innovative, inclusive and multilingual teaching methods. The European Commission also provides recommendations for the implementation of an integrated approach to the teaching and learning of foreign languages which was adapted in May 2019. Multilingual and literacy competencies are identified as one of the main competencies.

All European countries have unequivocally taken into account the need to take into account all standards and criteria developed by the Council of Europe. It is about the ideas and provisions which are set out in the main documents and addressed teaching - "European Language Portfolio", "Common European Recommendations on Language Education: Study, Teaching, Assessment", "Reform language exams with European guidelines in the area of language education and exam requirements."

Polish and Dutch educational institutions follow the rules of introducing "living material" into the educational process in their teaching. It means that students do their tasks using the newest material, data and research results, which are presented in English in the world information space. Universities in Poland and the Netherlands are happy to involve teachers and students in bilingual courses. It means that the same subject is taught in the state language and English and in this way they encourage students to study foreign languages. Still, they give their students the opportunity to use more understandable material if they find it too difficult to understand in English.

The number of courses that are taught in English exceeded the number of subjects in the state language at the University of Amsterdam: $62 \%$ of the curriculum was taught in English and only 38\% in the state language, the 
results were slightly lower in Poland, but almost 35\% of the program in Warsaw Polytechnic University can be listened in English.

There is a general practice of specialization of students in one foreign language in combination with another discipline in the Czech Republic, as well as in the Netherlands, Italy, Germany, Denmark, Malta, Romania and Austria. Czech higher education institutions have introduced incentives for students to learn a second foreign language in order to enable professionals to ensure the development of professional qualities. The choice of foreign languages for students is limited by providing the opportunity to learn English, German, French which is not very common language within the EU (Antonenko, 2015). Preparation for the usage of information and communication technologies is a mandatory moment of the curriculum in the country. Training courses are aimed to gain skills in the practice of learning a foreign language and the formation of information and communication skills and abilities.

The study of foreign languages in higher education institutions in the UK is a part of the so-called specialization courses. For example, language training programs for students are included in the curricula of the Universities of Sheffield, Edinburgh, Birmingham, Lancaster, the University of East London and other higher education institutions in the United Kingdom.

These programs are aimed at mastery of oral and written skills, learning a foreign language and getting acquainted with the literature of the country whose language is being studied. The course of these programs combines critical thinking technologies, which allows to improve the language training of students at different stages of learning a foreign language. Language training programs contribute to the mastery of oral communication skills, creative thinking, the ability to justify own opinion properly and ethically correct (Shulga, 2017).

A multicultural approach to learning helps to educate personal qualities among students. They might develop inner values, national consciousness. This approach promotes the practical interest of the student in the future usage and application of own knowledge. Language programs with multiculturalism are aimed at selecting grammatical and lexical material within the international variations in pronunciation. So, the multicultural approach to foreign-language teaching in higher education institutions in the UK in the context of the Bologna Process is a cornerstone in the formation of a solid European educational space.

Communication techniques are the most popular in language teaching in Denmark, Germany, the Netherlands and Spain. Focusing on communication and intercultural learning not only stimulates productive discussion of learning issues and methods, which are reflected in the plans and textbooks, but also results in an improved level of oral and written speech of students. For example, German and French are used in Luxembourg as a means of teaching other subjects throughout the study period in order to support the simultaneous study of both languages. Primary school students study subjects exclusively in a second or foreign language in European "bilingual" programs (Ponikarovska, 2015).

The study of the experience of teaching foreign languages in higher education institutions of the EU allows to identify the main areas for modernization of foreign language education:

1) From the form to the practice of teaching (the definition of educational achievements involves the development of skills in the usage of language and a foreign language instead of knowledge in order to develop communicative competencies);

2) Correctness is replaced by the effectiveness of knowledge of foreign languages (indisputable advantage in teaching is given to the ability of implementing all communication skills instead of knowledge of correct lexical and grammatical language expressions);

3) Flexibility in foreign-language learning (flexible curricula and foreign language teaching courses are introduced, focused on the individual and personal needs of students);

4) shifting the emphasis on communicativeness (curricula are developed on the priority of the communicative principle, different types of educational tasks and programs implement communicative intentions and promote the organization of fluent communication in a foreign language);

5) Development of plurilingual competence (development and training of plurilingual competence for the usage of possible non-verbal and verbal tools of meaning expression and realization of communicative competences);

6) The range of languages is expanded. They are offered for learning with priority of English, German and French (Kuznetsova, 2015).

First of all, European experts consider it necessary to modernize the language and pedagogical training of teachers in higher education institutions in order to implement certain tasks. The second element of the implementation of 
certain tasks of modernization of teacher training concerns the implementation of the establishment of a reliable link between pedagogical and linguistic training of future specialists. Teachers have to be qualified and flexible teaching specialists who are able to implement theoretical and practical pedagogical knowledge, skills and abilities in their own language learning and in teaching the languages of others. The third element of transformations in the training of professionals involves the establishing of organizational and substantive interaction between subject areas (linguistics, pedagogy) and between the departments that provide it, as well as in university policy and the attitude of the teaching staff.

\subsection{Cognition in Teaching Intercultural Communicative Competence}

The results of the survey on the perception and knowledge of intercultural communicative competence byteachers indicate the readiness of educators to implement an intercultural approach in teaching foreign languages in Ukrainian universities (Table 2). Nevertheless, the perception of intercultural competences as the best approach in teaching is at an average level (the mean value is 3,68), which may be related to teachers' assessment of the level of tolerance among students with knowledge of cultural differences (the mean value is 2,89).

Table 2. Ukrainian teachers' knowledge about intercultural communicative competence

\begin{tabular}{|c|c|c|c|c|}
\hline Statement & Mean & $\begin{array}{l}\text { Standard } \\
\text { deviation }\end{array}$ & Minimum & Maximum \\
\hline $\begin{array}{l}\text { I would like to teach intercultural competence in my } \\
\text { classroom. }\end{array}$ & 4.57 & 1.24 & 3 & 5 \\
\hline Intercultural education is best undertaken cross-circularly. & 3.68 & 0.99 & 3 & 4 \\
\hline $\begin{array}{l}\text { The more students know about the foreign culture, the more } \\
\text { tolerant they are. }\end{array}$ & 2.89 & 1.55 & 2 & 4 \\
\hline $\begin{array}{l}\text { All students should acquire intercultural competence, not } \\
\text { only students in classrooms with ethnic minority } \\
\text { community. }\end{array}$ & 4.12 & 0.89 & 3 & 5 \\
\hline $\begin{array}{l}\text { It is impossible to teach the foreign language and foreign } \\
\text { culture in an integrated way. }\end{array}$ & 2.23 & 1.12 & 1 & 3 \\
\hline $\begin{array}{l}\text { In a foreign language classroom, teaching culture is as } \\
\text { important as teaching the foreign language. }\end{array}$ & 3.55 & 1.65 & 1 & 4 \\
\hline $\begin{array}{l}\text { Every subject, not just foreign language teaching, should } \\
\text { promote the acquisition of intercultural skills. }\end{array}$ & 4.25 & 1.45 & 3 & 5 \\
\hline $\begin{array}{l}\text { Only when there are students of ethnic minority community } \\
\text { in your classes, you have to teach intercultural competence. }\end{array}$ & 2.56 & 0.78 & 1 & 4 \\
\hline $\begin{array}{l}\text { A foreign language teacher should present a positive image } \\
\text { of the foreign culture }\end{array}$ & 4.15 & 0.55 & 3 & 5 \\
\hline $\begin{array}{l}\text { Intercultural education has no effect whatsoever on } \\
\text { students' attitudes. }\end{array}$ & 1.01 & 0.15 & 1 & 2 \\
\hline
\end{tabular}

Source: author's research

On the whole, teachers consider the need to obtain intercultural competences in general (Table 3) (average 4,12 with a deviation of 0,89). Educators recognize an integrated approach in teaching foreign languages and foreign culture (average 2,23 and deviation 1,12). The study of the culture of foreigners is determined by teachers as important as the study of a foreign language (the average is 3,55 with a deviation of 1,65). Educators also consider the significant contribution of each subject to the development of intercultural competences (average 4,25 with a deviation of 1,45) and the importance of an intercultural approach, despite the number of ethnic minorities (average 2,56 with a deviation of 0,78). Educators recognize their own value and significance in the formation of a positive attitude of students to foreign culture (average 4,15 with a deviation of 0,55); they emphasize the effectiveness of the intercultural approach in learning foreign languages, despite the attitude and views of students (average 1,01 with a deviation of 0,15$)$. 
Table 3. The relationship between teachers' knowledge about intercultural communicative competence

\begin{tabular}{|c|c|c|c|c|c|c|c|c|c|c|}
\hline & 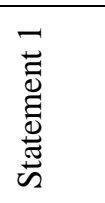 & 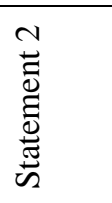 & 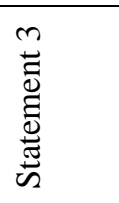 & 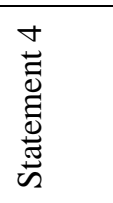 & 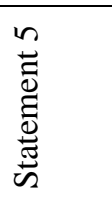 & 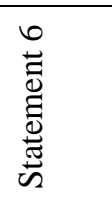 & 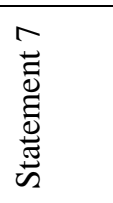 & 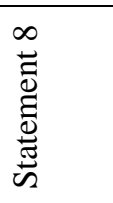 & 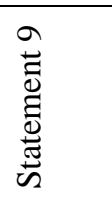 & 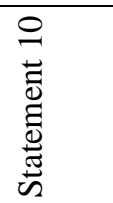 \\
\hline Statement 1 & 1 &, $389^{* *}$ & ,028 &,- 009 & ,039 & ,025 &,- 037 &,- 031 &, $056^{*}$ &,- 002 \\
\hline Statement 2 &, $389^{* *}$ & 1 &, $108^{* *}$ &, $119^{* *}$ &,- 015 &, $127^{* *}$ &,$- 096^{* *}$ &,$- 077^{* *}$ &, $113^{* *}$ &,- 042 \\
\hline Statement 3 & , 028 &, $108^{* *}$ & 1 &,$- 134^{* *}$ &,- 045 &, $122^{* *}$ &,$- 122^{* *}$ &,$- 095^{* *}$ & ,041 &,$- 144^{* *}$ \\
\hline Statement 4 &,- 009 &, $119^{* *}$ &,$- 134^{* *}$ & 1 &, $071^{* *}$ &, $107^{* *}$ &, $072^{* *}$ &, $073^{* *}$ &,- 049 &,- 009 \\
\hline Statement 5 & ,039 &,- 015 &,- 045 &, $071^{* *}$ & 1 &, $161^{* *}$ & ,001 &, $054^{*}$ &,- 006 &,$- 089^{* * *}$ \\
\hline Statement 6 & ,025 &, $127^{* *}$ &, $122^{* *}$ &, $107^{* *}$ &, $161^{* *}$ & 1 &,$- 158^{* *}$ &,$- 091^{* *}$ &, $080^{* *}$ & ,033 \\
\hline Statement 7 &,- 037 &,$- 096^{* *}$ &,$- 122^{* *}$ &, $072^{* *}$ & , 001 &,$- 158^{* *}$ & 1 &, $103^{* *}$ &,$- 140^{* * *}$ &, 015 \\
\hline Statement 8 &,- 031 &,$- 077^{* *}$ &,$- 095^{* *}$ &, $073^{* *}$ &, $054^{*}$ &,$- 091^{* *}$ &, $103^{* *}$ & 1 &,$- 187^{* *}$ &,- 031 \\
\hline Statement 9 &, $056^{*}$ &, $113^{* *}$ & , 041 &,- 049 &,- 006 &, $080^{* *}$ &,$- 140^{* *}$ &,$- 187^{* *}$ & 1 &,$- 126^{* *}$ \\
\hline Statement 10 &,- 002 &,- 042 &,$- 144^{* *}$ &,- 009 &,$- 089^{* *}$ & ,033 & ,015 &,- 031 &,$- 126^{* *}$ & 1 \\
\hline
\end{tabular}

Source: author's research. Note: $\mathrm{N}=32 .{ }^{*} \mathrm{p}<0.05,{ }^{* *} \mathrm{p}<0.01$.

The desire to teach a foreign language correlates with the positive attitude of teachers to cross-cultural teaching of foreign languages $(0,389)$. A positive attitude to cross-cultural teaching of foreign languages is favorably correlated with: 1) the attitude of teachers to students' needs of acquiring intercultural competences (both ethnic minorities and other students) $(0,119) ; 2)$ recognition of the need to learn a foreign culture. A negative connection has been revealed between the assessment of the foreign culture / tolerance and 1) the recognition of the need to acquire intercultural competences $(-0,134) ; 2)$ the recognition of the need to study intercultural competences only in the presence of ethnic minorities $(-0,122) ; 3)$ recognition of the lack of influence on students' attitudes $(-0,144)$. A positive direct connection has been revealed between the assessment of the relation of knowledge of foreign culture / tolerance and the importance of teaching foreign culture $(0,122)$. Recognition of the importance of acquiring intercultural competences by all students; the possibility of integrating the teaching a foreign language and culture are at the same time positively related to the importance of acquiring knowledge about culture and learning a foreign language (0,107 and 0,161, respectively). Negative connection between: 1$)$ assessment of the possibility of integrating foreign language and culture teaching at the same time and the importance of foreign language and culture teaching $(-0,158)$; 2) the importance of teaching a foreign language and culture and assessing the role of the teacher in the image formation of a foreign culture $(-0,140) ; 3)$ the possibility of studying intercultural competences only in the presence of ethnic minorities and assessing the role of the teacher in image formation of foreign culture $(-0,187) ; 4)$ assessment of the teacher's role in the image formation of foreign culture and assessment of the lack of influence of the intercultural approach on the attitude of students $(-0,126)$.

\section{Discussion}

Teaching foreign languages is part of social integration policy, particularly within the EU (Cullen, 2017). As a result, new approaches and innovations are integrated into the teaching process. New types of organizations are beginning to develop and usage of new approaches to language learning in order to provide innovative services aimed at supporting the integration of immigrants into society (Cullen, 2017).

Teaching models are characterized by interdisciplinarity and are based on synergetic principles. This is due to the formation of a new learning environment as an open complex system that is constantly developing (Gural, 2014). 
The principle of intercultural approach is one of the fundamental in teaching within this model (Yang et al., 2018). As a result, the practice and models of teaching intercultural languages are formed in order to "develop students' intercultural communicative competence" (Tolosa et al., 2018). The consequence of such changes is "linguistic diversity" on a global scale (Dendrinos, 2018).

"The official rhetoric of the European Union (EU) describes the linguistic diversity by which it is characterised as 'an asset for Europe and a shared commitment', while it also represents languages as commodities for employability, mobility and economic growth" (Dendrinos, 2018). Studying foreign languages is politically regulated, as it affects the provision of the labor market by professionals."Language learning has long been seen as an important tool for achieving European Union (EU) targets for social inclusion" (Cullen, 2017). It is obvious that the policy of inclusion pursues social-economic goals. Inclusion primarily concerns migrants who are supported by EU governments "by providing language and professional training' (Kancs \& Lecca, 2018). EU policy in this area has spread far beyond the EU (Gazzola, 2016). However, despite the "consistency" within EU on language policy, there are still significant differences in the number of languages taught at different levels of education (Romanowski, 2016).

Studying foreign languages is characterized by the problem of providing the educational system with teachers within EU due to the unattractiveness of the teaching profession (Koglbauer, 2018). Recruitment companies continue to "target French-, German- and Spanish-speaking countries in order to deal with the language teacher supply issue" (Koglbauer, 2018). This issue is exacerbated by the problems of the quality of teachers' training and advanced training at the primary level (Koglbauer, 2018).

\section{Conclusion}

It is established taking into account the analysis of data and research results of European researchers:

1) changes in the social and economic context require new approaches to the organization and provision of foreign language education;

2) a new understanding of the aim of "language learning" leads to the formation of new models of their learning. The emphasis shifts from the skill of knowledge and correctness to communicative competencies in the foreign-language teaching, which ensures an effective result. The new models are created to train a professional who can effectively communicate, listen, understand the intercultural speaker etc. Therefore, the emphasis in teaching shifts from the obtaining the expected result to achieving motivating effective achievements, from the process of language learning to the process of "language usage". Any available resources can be used in order to achieve new results, leading to a new understanding of the role pedagogy. Today it is emphasized that teachers should be prepared for professional specialized work in a multicultural, multilingual, ethnically diverse environment. Educators of higher educational institutions are ready to implement an intercultural approach in teaching foreign languages.

3) shifting from linguistic purity and correctness and the priority of a democratic society, openness to different cultures indicate that the social and educational environment are multilingual. This poses new challenges to education, which is expected to be flexible and to develop tools that can prepare teachers to respond adequately to all changes. Educational priorities are shifted to the individual and the requirements of the environment. The aim of mastering a language is not a competence in a foreign language, but intercultural communicative competence based on the needs of specific communication situations. The formation of tolerance to the usage of language "hybridity" has become a priority instead of wishing to succeed in mastering a foreign language at the level of certain standards.

\section{References}

Antonenko, O. V. (2015). Professional training of foreign language teachers in the context of modernization of higher education in the Czech Republic. Problems and prospects of formation of the national humanitarian and technical elite: a collection of scientific works, 43(47), 326-331.

Arrosagaray, M., González-Peiteado, M., Pino-Juste, M., \& Rodríguez-López, B. (2019). A comparative study of Spanish adult students' attitudes to ICT in classroom, blended and distance language learning modes. Computers \& Education, 134, 31-40. https://doi.org/10.1016/j.compedu.2019.01.016

Bilyalova, A. (2017). ICT in Teaching a Foreign Language in High School. Procedia - Social and Behavioral Sciences, 237, 175-181. https://doi.org/10.1016/j.sbspro.2017.02.060

Bukach, V., \& Golubova, G. (2019). Country Studies in teaching foreign languages at higher school. Scientific bulletin of South Ukrainian National Pedagogical University named after K. D. Ushynsky, 4(129), 26-32.

Calafato, R. (2019). The non-native speaker teacher as proficient multilingual: A critical review of research from 2009-2018. Lingua, 227, 102700. https://doi.org/10.1016/j.lingua.2019.06.001 
Cappellari, L., \& Di Paolo, A. (2018). Bilingual schooling and earnings: Evidence from a language-in-education reform. Economics of Education Review, 64, 90-101. https://doi.org/10.1016/j.econedurev.2018.03.007

Cullen, J. (2017). Migrants and the language of instruction: Is the EU policy deficit driving new innovations in social inclusion? International Review of Education, 63(4), 453-474. ttps://doi.org/10.1007/s11159-017-9635-4

Dendrinos, B. (2018). Multilingualism language policy in the EU today: A paradigm shift in language education. Training, Language and Culture, 2(3), 9-28. https://doi.org/10.29366/2018tlc.2.3.1

EUR-lex: Access to Eropean Union law. (2019). Council Recommendation of 22 May 2019 on a comprehensive approach to the teaching and learning of languages. Retrieved from https://eur-lex.europa.eu/legal-content/EN/TXT/?uri=CELEX\%3A32019H0605\%2802\%29

Eurostat. (2019a). Foreign language learning statistics: Statistics Explained. Retrieved from https://ec.europa.eu/eurostat/statistics-explained/pdfscache/1151.pdf

Eurostat. (2019b). What proportion of pupils learn two or more foreign languages (\% of pupils in upper secondary general education). Retrieved from https://ec.europa.eu/eurostat/statistics-explained/index.php?title=File:What_proportion_of_pupils_learn_two_or _more_foreign_languages_(\%25_of_pupils_in_upper_secondary_general_education)_ET19.png

Eurostat. (2020). Pupils by education level and number of modern foreign languages studied - absolute numbers and $\%$ of pupils by number of languages studied. Retrieved from https://appsso.eurostat.ec.europa.eu/nui/show.do?dataset=educ_uoe_lang02\&lang=en

Gazzola, M. (2016). EU language policy and English. In A. Linn (Ed.), Investigating English in Europe: Contexts and agendas. English in Europe (pp. 138-144). Berlin, Germany: Walter de Gruyter, Inc. https://doi.org/10.1515/9781614518952-024

Grigorieva, E. (2014). Language teaching content renovation in the context of higher education internationalization. Procedia - Social and Behavioral Sciences, 152, 1143-1147. https://doi.org/10.1016/j.sbspro.2014.09.290

Gural, S. K. (2014). A new approach to foreign language discourse teaching as a super-complex, self-developing system. Procedia - Social and Behavioral Sciences, 154, 3-7. https://doi.org/10.1016/j.sbspro.2014.10.103

Kancs, D. A., \& Lecca, P. (2018). Longterm social, economic and fiscal effects of immigration into the EU: The role of the integration policy. The World Economy, 4l(10), 2599-2630. https://doi.org/10.1111/twec.12637

Klimova, B. F., \& Kacetl, J. (2015). Hybrid learning and its current role in the teaching of foreign languages. Procedia - Social and Behavioral Sciences, 182, 477-481. https://doi.org/10.1016/j.sbspro.2015.04.830

Klimova, B. F., \& Semradova, I. (2012). The teaching of foreign languages and ICT. Procedia Technology, 1, 89-93. https://doi.org/10.1016/j.protcy.2012.02.017

Koglbauer, R. (2018). Language teacher supply: The vicious cycle, the effects of the EU referendum and attempts to solve supply shortage. In Kelly M. (Eds.), Languages after Brexit (pp. 219-227). Cham, Switzerland: Palgrave Macmillan. https://doi.org/10.1007/978-3-319-65169-9_19

Kuznetsova, O. (2015). Foreign language education in modern European socio-economic realities. Collection of scientific works, 51, 25-29.

Lochmann, A., Rapoport, H., \& Speciale, B. (2019). The effect of language training on immigrants' economic integration: Empirical evidence from France. European Economic Review, 113, 265-296. https://doi.org/10.1016/j.euroecorev.2019.01.008

Lorenzo, F., Granados, A., \& Ávila, I. (2019). The development of cognitive academic language proficiency in multilingual education: Evidence of a longitudinal study on the language of history. Journal of English for Academic Purposes, 41, 100767. https://doi.org/10.1016/j.jeap.2019.06.010

Oktay, A. (2015). Foreign language teaching: A problem in Turkish education. Procedia - Social and Behavioral Sciences, 174, 584-593. https://doi.org/10.1016/j.sbspro.2015.01.587

Pérez-Llantada, C. (2018). Bringing into focus multilingual realities: Faculty perceptions of academic languages on campus. Lingua, 212, 30-43. https://doi.org/10.1016/j.lingua.2018.05.006

Ponikarovska, S. V. (2015). Peculiarities of teaching foreign languages in the countries of Western Europe. Pedagogy of formation of creative personality in higher and general education schools, 40(93), 255-258. 
Pozdeeva, S., \& Obskov, A. (2015). Justification of the Main Pedagogical Conditions of Interactive Teaching a Foreign Language in High School. Procedia - Social and Behavioral Sciences, 206, 166-172. https://doi.org/10.1016/j.sbspro.2015.10.047

Prokhorets, E. K., Sysa, E. A., \& Rudneva, E. L. (2015). Teaching of Autonomous Foreign Language Reading in Technical University: Criteria for the Selection of Textual Material. Procedia - Social and Behavioral Sciences, 215, 256-259. https://doi.org/10.1016/j.sbspro.2015.11.631

Romanowski, P. (2016). A statistical analysis of the state of foreign language learning in the EU. Lingwistyka

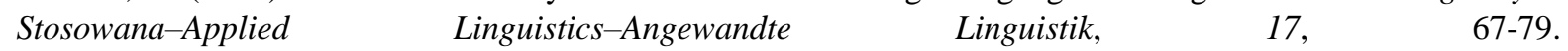
https://doi.org/10.32612/uw.20804814.2016.2.pp.67-79

Sercu, L. (2006). Foreign Language Teachers and Intercultural Competence Teaching. International Journal of Applied Linguistics, 151, 15-32. https://doi.org/10.2143/ITL.151.0.2015220.

Shulga, N. V. (2017). Multicultural approach to foreign language teaching in the system of higher education in schools in the United Kingdom. Collection of scientific works of Uman State Pedagogical University, 1, 45-49.

Tolosa, C., Biebricher, Ch., East, M., \& Howard, J. (2018). Intercultural language teaching as a catalyst for teacher inquiry. Teaching and Teacher Education, 70, 227-235 https://doi.org/10.1016/j.tate.2017.11.027

Yang, G., Xiang, H., \& Chun, L. (2018). Chinese as a second language teachers' cognition in teaching intercultural communicative competence. System, 78, 224-233. https://doi.org/10.1016/j.system.2018.09.009 